\title{
PENERAPAN REGRESI GENERALIZED POISSON UNTUK MENGATASI FENOMENA OVERDISPERSI PADA KASUS REGRESI POISSON
}

\author{
I Putu Yudanta Eka Putra ${ }^{1}$, I Putu Eka Nila Kencana ${ }^{2}$, \\ I GUSTI AYU MADE SRINADI ${ }^{3}$ \\ 1,2,3 Jurusan Matematika FMIPA Universitas Udayana, Bukit Jimbaran-Bali \\ e-mail: ${ }^{1}$ yudantaekaputra@yahoo.com , ${ }^{2}$ i.putu.enk@gmail.com, \\ ${ }^{3}$ srinadiigustiayumade@yahoo.co.id
}

\begin{abstract}
The Poisson regression is generally used to analyze the response variable that is a discrete data. Poisson regression has assumption which must be met, that is condition equidispersion. But in fact this assumption is often violated, that is the value of the variance is greater or less than the mean value. The condition when value of the variance is greater than the mean value is called overdispersion. One method that can be used for overdispersion data is Generalized Poisson regression. In this research, it was found that the Generalized Poisson regression method was better than Poisson regression method.
\end{abstract}

Keywords: Poisson Regression, Overdispersion, Generalized Poisson regression.

\section{Pendahuluan}

Analisis regresi Poisson merupakan metode regresi yang digunakan untuk menganalisis data yang variabel responnya berupa data diskret. Pada regresi Poisson terdapat asumsi yang harus dipenuhi, yaitu nilai varians dan rata-rata dari variabel respon tersebut sama atau equidispersi (Myers et al. [3]). Namun dalam kenyataan di lapangan sering terjadi pelanggaran asumsi tersebut, yaitu nilai variansnya lebih besar dari nilai rata-rata yang dinamakan overdispersi atau nilai variansnya lebih kecil dari nilai rata-rata yang dinamakan underdispersi (Wang \& Famoye [5]). Jika terjadi fenomena overdispersi pada data, maka regresi Poisson kurang akurat digunakan untuk analisis, karena berdampak pada nilai standard error menjadi under estimate (lebih kecil dari nilai sesungguhnya), sehingga kesimpulan yang diperoleh menjadi tidak valid (McCullagh \& Nelder [2]). Untuk mengatasi masalah overdispersi tersebut, salah satu metode yang dapat digunakan adalah analisis regresi Generalized Poisson yang merupakan perluasan dari regresi Poisson.

Tujuan penelitian ini adalah untuk mengetahui model regresi Poisson dan model regresi Generalized Poisson untuk data variabel respon yang mengalami

\footnotetext{
${ }^{1}$ Mahasiswa Jurusan Matematika FMIPA Universitas Udayana

${ }^{2,3}$ Staf Pengajar Jurusan Matematika FMIPA Universitas Udayana
} 
overdispersi, dan mengetahui metode analisis regresi yang lebih baik digunakan untuk data variabel respon mengalami overdipersi apabila dilihat dari nilai Pearson chi-square, AIC (Akaike's Information Criterion), BIC (Bayesian Information Criterion), Log likelihood dan Likelihood ratio.

Kondisi overdispersi dapat dilihat dari nilai taksiran dispersi yaitu nilai Pearson chi-square/df dan Devianceldf nilai keduanya lebih besar dari 1, kemudian dilanjutkan dengan melakukan uji rasio dispersi $(\alpha)$ (Setyawan [4]) untuk mempertegas nilai taksiran dispersi. Metode yang dapat digunakan menganalisis data yang mengalami overdispersi salah satunya adalah regresi Generalized Poisson, regresi Generalized Poisson merupakan perluasan dari regresi Poisson yang dapat mengatasi keadaan overdispersi/underdispersi (Wang \& Famoye [5]). Hubungan nilai rata-rata dan varians dalam regresi Generalized Poisson dapat dikondisikan sebagai berikut, 1) Jika nilai varians sama dengan nilai rata-rata $E\left(Y_{i} \mid x_{i}\right)=\operatorname{Var}\left(Y_{i} \mid x_{i}\right)$, maka nilai parameter dispersi $k=0$, sehingga fungsi densitas peluang Generalized Poisson, akan diturunkan ke regresi Poisson. 2) Jika nilai varians lebih besar dari nilai rata-rata $E\left(Y_{i} \mid x_{i}\right)<$ $\operatorname{Var}\left(Y_{i} \mid x_{i}\right)$, maka nilai parameter disperse $k>0$, sehingga dapat dikatakan pada data terjadi overdispersi. 3) Jika nilai varians lebih kecil dari pada nilai rata-rata $E\left(Y_{i} \mid x_{i}\right)>\operatorname{Var}\left(Y_{i} \mid x_{i}\right)$, maka nilai parameter dispersi $k<0$, sehingga pada data terjadi underdispersi.

Pada penelitian ini dalam menentukan metode analisis terbaik antara regresi Poisson dengan regresi Generalized Poisson dapat dilihat dari nilai Pearson chi-squareldf, AIC, BIC, Log likelihood, dan Likelihood ratio, dengan kriteria nilai Pearson Chi-square yang mendekati $d f$ yang lebih baik, nilai AIC dan BIC yang mempunyai nilai lebih kecil menunjukkan model yang lebih baik, dan nilai Log likelihood yang mempunyai nilai lebih besar menunjukkan metode yang lebih baik Perbedaan antara metode regresi Poisson dan regresi Generalized Poisson secara teori disajikan pada Tabel 1. 
Tabel 1. Perbedaan Regresi Poisson dengan Regresi Generalized Poisson

\begin{tabular}{|c|c|c|}
\hline Kriteria & Poisson & Generalized Poisson \\
\hline $\begin{array}{l}\text { Fungsi } \\
\text { densitas }\end{array}$ & $f\left(y_{i}\right)=\frac{e^{-\mu_{i}} \mu_{i}^{y_{i}}}{y_{i} !}$ & $\begin{array}{l}P\left(Y_{i}=y_{i}\right) \\
=\left(\frac{\mu_{i}}{1+k \mu_{i}}\right)^{y_{i}} \frac{\left(1+k y_{i}\right)^{y_{i}-1}}{y_{i} !} \exp \left(\frac{\mu_{i}\left(1+k y_{i}\right)}{1+k \mu_{i}}\right)\end{array}$ \\
\hline $\begin{array}{l}\text { Rata-rata } \\
\text { dan ragam }\end{array}$ & $E(y)=\operatorname{Var}(y)=\mu$ & $\begin{array}{c}E(y)=\mu \\
\operatorname{Var}(y)=\mu_{i}\left(1+k \mu_{i}\right)^{2}\end{array}$ \\
\hline $\begin{array}{l}\text { Penduga } \\
\text { parameter }\end{array}$ & $\begin{array}{c}\text { Maximum likelihood } \\
\frac{\prod_{i=1}^{n} \mu_{i} y_{i} \exp \left(-\sum_{i=1}^{n} \mu_{i}\right)}{\prod_{i=1}^{n} y_{i} !}\end{array}$ & $\prod_{i=1}^{n}\left\{\begin{array}{c}\text { Maximum Likelihood } \\
\left(\frac{\exp \left(\beta_{0}+\sum_{j=1}^{p} \beta_{j} x_{j i}\right)}{1+\mathrm{k} \exp \left(\beta_{0}+\sum_{j=1}^{p} \beta_{j} x_{j i}\right)}\right)^{y_{i}} \frac{\left(1+k y_{i}\right)^{y_{i}-1}}{y_{i} !} \\
\exp \left(\frac{\exp \left(\beta_{0}+\sum_{j=1}^{p} \beta_{j} x_{j i}\right)\left(1+k y_{i}\right)}{1+k \exp \left(\beta_{0}+\sum_{j=1}^{p} \beta_{j} x_{j i}\right)}\right)\end{array}\right)$ \\
\hline $\begin{array}{c}\text { Uji } \\
\text { signifikansi }\end{array}$ & $\begin{array}{l}W=\left(\frac{\hat{\beta}_{j}}{S E\left(\hat{\beta}_{j}\right)}\right)^{2} \\
H_{0}: \beta_{j}=0 \\
H_{1}: \beta_{j} \neq 0\end{array}$ & $W=\left(\frac{\hat{\beta}_{j}}{S E\left(\hat{\beta}_{j}\right)}\right)^{2}$ \\
\hline $\begin{array}{c}\text { Parameter } \\
\text { disperse }\end{array}$ & - Try & $K$ \\
\hline Model & $y_{i}=\exp \left(x_{i}^{T} \hat{\beta}\right)$ & $y_{i}=\exp \left(x_{i}^{T} \hat{\beta}\right)$ \\
\hline
\end{tabular}

\section{Metode Penelitian}

Data yang digunakan pada penelitian ini adalah data sekunder yang diperoleh dari Dinas Pendidikan Pemuda dan Olahraga Provinsi Bali, berupa variabel respon pada penelitian ini adalah jumlah siswa SMA/SMK yang tidak lulus UN tahun 2012 tiap kabupaten di Provinsi Bali. Variabel bebas pada penelitian ini adalah jumlah sekolah SMA/SMK negeri tiap kabupaten di Provinsi Bali, jumlah ruang kelas SMA/SMK rusak tiap kabupaten di Provinsi Bali, jumlah guru S2 untuk SMA/SMK tiap kabupaten di Provinsi Bali, jumlah siswa SMA/SMK yang mengikuti UN tiap kabupaten di Provinsi Bali.

Adapun langkah-langkah analisis pada penelitian ini ialah mendeskripsikan data siswa SMA/SMK yang tidak lulus UN 2012 di Provinsi Bali, selanjutnya mencari model regresi Poisson dari data dan memeriksa terjadinya overdispersi, kemudian melakukan analisis data menggunakan analisis regresi Generalized Poisson, setelah itu mencari metode analisis yang lebih baik antara analisis regresi Poisson dengan regresi Generalized Poisson apabila dilihat dari kriteria Pearson Chi-square, AIC, BIC, Likelihood ratio (Ismail \& Jemain [1]), dan sebagai langkah terakhir adalah menginterpretasi hasil perbandingan dari model regresi Poisson dan Generalized Poisson. 


\section{Hasil dan Pembahasan}

Deskripsi data siswa SMA/SMK tidak lulus UN 2012 pada penelitian ini disajikan pada Tabel 2.

Tabel 2. Deskripsi Data Penelitian

\begin{tabular}{|l|c|c|c|c|c|}
\hline & $\mathrm{X}_{1}$ & $\mathrm{X}_{2}$ & $\mathrm{X}_{3}$ & $\mathrm{X}_{4}$ & $\mathrm{Y}$ \\
\hline Mean & 10,89 & 125,90 & 34,11 & 4983,00 & 4,11 \\
\hline Simpangan Baku & 4,57 & 291,90 & 13,75 & 2512,00 & 5,42 \\
\hline Ragam/Mean & 1,91 & 676,77 & 5,54 & $1.266,33$ & 7,14 \\
\hline Nilai Minimum & 7 & 12 & 17 & 2171 & 0 \\
\hline Nilai Maksimum & 22 & 903 & 58 & 10176 & 17 \\
\hline
\end{tabular}

Model full regresi Poisson dari data yang dianalisis adalah sebagai beriku:

$$
\mu=\exp \left(-1,2261+0,1619 X_{1}+0 X_{2}-0,0299 X_{3}+0,0002 X_{4}\right)
$$

Selanjutnya dilakukan pemeriksaan overdispersi dengan menghitung nilai taksiran dispersi seperti disajikan pada Tabel 3 berikut:

Tabel 3. Taksiran Dispersi

\begin{tabular}{|c|c|c|c|}
\hline kriteria & df & Nilai & nilai/df \\
\hline Deviance & 4 & 21,8662 & 5,4666 \\
\hline Pearson Chi-square & 4 & 19,3321 & 4,8330 \\
\hline
\end{tabular}

Namun untuk lebih jelasnya akan dilakukan uji lanjutan mengunakan uji statistika rasio dipersi ( $a$ ) dengan hipotesis uji sebagai berikut

$H_{0}: a=1$ (pada data tidak terjadi overdispersi)

$H_{1}: a>1$ (pada data terjadi overdispersi)

dengan statistik uji nilai deviance yaitu $21,8662>\chi_{0.05,4}^{2}=9,48773$, yang berarti $H_{0}$ ditolak. Hal ini menunjukkan bahwa terjadi overdispersi pada regresi Poisson. Oleh karena itu, selanjutnya akan dianalisis dengan menggunakan metode regresi Generalized Poisson.

Model full regresi Generalized Poisson dari data yang dianalisis adalah:

$$
\mu=\exp \left(-1,4116+0,3425 X_{1}+0,000592 X_{2}-0,1548 X_{3}+0,000573 X_{4}\right)
$$

Untuk menentukan metode yang terbaik berikut disajikan Tabel Kriteria Model

Tabel 4. Kriteria Model

\begin{tabular}{|c|c|c|}
\hline Kriteria & Poisson & Generalized Poisson \\
\hline Pearson Chi-square & 19,3321 & 4,64 \\
\hline AIC & 53,8532 & 52,30 \\
\hline BIC & 54,8393 & 53,48 \\
\hline Log Likelihood & $-21,9266$ & $-20,15$ \\
\hline
\end{tabular}

Berdasarkan Tabel 4, dapat diketahui metode regresi Generalized Poisson lebih baik dari pada regresi Poisson. Namun untuk lebih mpertegas berikut disajikan Tabel nilai Standard Error 
Tabel 5. Nilai Standard Error

\begin{tabular}{|c|c|c|}
\hline $\begin{array}{c}\text { Variabel } \\
\text { bebas }\end{array}$ & $\begin{array}{c}\text { Standar error regresi } \\
\text { Poisson }\end{array}$ & $\begin{array}{c}\text { Standar error regresi Generalized } \\
\text { Poisson }\end{array}$ \\
\hline Intercept & 0,6900 & 1,338500 \\
\hline $\mathrm{X} 1$ & 0,0822 & 0,292200 \\
\hline $\mathrm{X} 2$ & 0,0009 & 0,001571 \\
\hline $\mathrm{X} 3$ & 0,0509 & 0,180500 \\
\hline $\mathrm{X} 4$ & 0,0002 & 0,000587 \\
\hline
\end{tabular}

Berdasarkan nilai standard error yang disajikan pada tabel 5 terlihat nilai standard error pada regresi Generalized Poisson mengalami peningkatan atau under estimate yang terjadi pada regresi Poisson telah diatasi sehingga metode Generalized Poisson lebih baik.

\section{Kesimpulan}

Berdasarkan data ketidaklulusan siswa SMA/SMK dalam mengikuti UN 2012 yang diperoleh dari Dinas Pendidikan Pemuda dan Olahraga Provinsi Bali yang telah dianalisis menggunakan software SAS 9.2, model regresi Poisson yang diperoleh untuk data tersebut adalah

$$
\mu=\exp \left(-1,2261+0,1619 X_{1}+0 X_{2}-0,0299 X_{3}+0,0002 X_{4}\right)
$$

Sedangkan model regresi Generalized Poisson yang diperoleh adalah $\mu=\exp \left(-1,4116+0,3425 X_{1}+0,000592 X_{2}-0,1548 X_{3}+0,000573 X_{4}\right)$

Dilihat dari kriteria model terbaik yaitu nilai Pearson Chi-square, AIC, BIC, Log Likelihood, dan Likelihood Ratio maka dapat disimpulkan metode regresi Generalized Poisson lebih baik untuk menganalisis.

\section{Daftar Pustaka}

[1] Ismail, Noriszura \& Abdul Aziz Jemain. 2005. "Generalized Poisson Regression: An Alternative For Risk Classification”. Jurnal Teknologi, 43, 1, 39-50. http://www.jurnalteknologi.utm. diakses tanggal 21 Oktober 2012.

[2] McCullagh, P. \& Nelder, J.A. 1989. Generalized Linier Models, second edition. London: Chapman \& Hall.

[3] Myers, R.H., Montgomery, D.C., Vining, G.G., \& Robinson, T.J. 2010. Generalized Linier Models with Aplications in Engineering and the Sciences. Canada : A John Wiley \& Sons, Inc., Publication.

[4] Setyawan, Aji. 2012. "Perbandingan antara Regresi Poisson, Binomial Negatif dan Zero-Inflated Poisson pada Data Overdispersi. [Skripsi]. http://www.repository.ipb.ac.id pada tanggal 21 Maret 2013.

[5] Wang, W. \& Famoye, F. 1997. Modeling household fertility decision with generalized Poisson regression. Journal of Population Economics, 10, 3, 273283. http://www.jstor.org diakses pada tanggal 27 Januari 2013. 